\title{
Performance and Evolution of Touchi Gurma Weeder with Developed Self-propelled Power Unit
}

\author{
B. Krishna Kanth ${ }^{1 *}$, A. K. Shrivastava ${ }^{2}$ and Jitendra Bairwa ${ }^{1}$ \\ ${ }^{1}$ Department of FMPE, Dr. NTR College of Agricultural Engineering, Bapatla, India \\ ${ }^{2}$ Department of FMPE, College of Agricultural Engineering, Jabalpur, India \\ *Corresponding author
}

A B S T R A C T

\begin{abstract}
Keywords
Self-propelled, Power weeder, Rotary weeder, Power unit, Weeder, Paddy, Tauchi gurma weeder

\section{Article Info}

\section{Accepted:}

10 January 2021

Available Online:

10 February 2021

Weeds are the major reason for economic losses in paddy production. Despite advances made in weed control, they continue to cause serious crop losses. Presently in Eastern Madhya Pradesh, majorly weeding in machine transplanted paddy fields was done by manually operated touchi gurma which is labor-intensive and time-consuming. A selfpropelled power unit is developed at the workshop of CAE, JNKVV, Jabalpur, powered by the Honda engine of 1.3 (hp) petrol engines. The objective of this research to do performance and evaluation of Touchi gurma with and without self-propelled power unit. It was found that the self-propelled power unit with Touchi gurmahas a field capacity of $0.0167 \mathrm{ha} / \mathrm{h}$ with $91 \%$ weeding efficiency and $77.65 \%$ field efficiency. Similarly, for manually operated Touchi gurma has afield capacity of 0.0099 ha/h with $81.49 \%$ weeding efficiency and $80 \%$ field efficiency. Among the two weeders, man-hours are required for a hectare field is59.35 man-h/ha for a self-propelled unit with a Touchi gurma as compared with a manually operated Touchi gurma i.e., $100.20 \mathrm{man}-\mathrm{h} / \mathrm{ha}$. The operational cost of weeding was maximum in manually operated Touchi gurma of $3131.25 \mathrm{Rs} / \mathrm{ha}$ as compared with self-propelled unit Touchi gurma of $1871.25 \mathrm{Rs} / \mathrm{ha}$.
\end{abstract}

\section{Introduction}

Rice (Oryza sativa L.) is a staple food for more than $60 \%$ of the world population. Asia holds the share of $90 \%$ from worlds rice production and utilization (FAO 2014). India holds $2^{\text {nd }}$ place in rice production and share added about $21.65 \%$ of total rice production of the world. In India, rice is cultivated in an area of 43.19 million hectare, annually with a production of 163.70 million tonne and yield of $3790 \mathrm{~kg} / \mathrm{ha}$ (Agricultural Statistics at a
Glance 2018). In Madhya Pradesh rice is grown in an area of 2.06 million hectares with production of 4.12 million tonne with yield of $2026 \mathrm{~kg} / \mathrm{ha}$. Weeds are major reason for economic losses in crop production. The estimated yield loss due to weed about 16-42 $\%$ based on type of crop and location and in terms of cultivation cost it was estimated about one-third of the total cost of cultivation (Rangasamy et al., 1993). Technologies based on resource conservation are becoming progressively important in rice system 
because these technologies will increase net profit of farmers and cut the production cost (Singh et al., 2016). Mechanical weeding reduces competition with weed and improves root growth by increasing soil aeration and root pruning which ultimately results in an increased number of tillers per plant (Vijayakumar et al., 2006).In Madhya Pradesh paddy the transplanting was done by rope line method. Early maturing varieties should be planted at a spacing of $20 \times 20 \mathrm{~cm}$ and medium and late varieties should be planted at a spacing of $25 \times 25 \mathrm{~cm}$. In this method at early stage of paddy crop, there is chances for increasing the weed infestation. For this, often use Tauchi Gurma. Touchi gurma is a manually operated mechanical weeder having the working width of $100 \mathrm{~cm}$ for manually operated weeders high energy required to perform weeding operation in wet land. It is also concluded that manual method of weeding operation requires more time and also increase the physiological response of the worker. Therefore, the operator cannot operate for a longer period of time without fatigue. The objective of this research was to performance and evaluation touchi gurma weeder with and without developed selfpropelled power unit.

\section{Materials and Methods}

\section{Rotary weeder (Touchi Gurma)}

It is also known by name of Touchi gurma as shown in Figure 2.1, the weeder consists of the following components; handle, frame, handle and float joint pipe, blade, float, blade holding shaft and nut bolt. Table 2.1 Reveled that the overall length of weeder ls $1550 \mathrm{~mm}$, width of $540 \mathrm{~mm}$ and height from the ground surface is $1020 \mathrm{~mm}$. The weight of weeder is $3.4 \mathrm{~kg}$. It consists of two rotary units with working width of $80 \mathrm{~mm}$. The diameter of hands is $14 \mathrm{~mm}$. Thickness of blade is $2 \mathrm{~mm}$. The size of float is $460 \mathrm{~mm}$ in length, $120 \mathrm{~mm}$ width and $25 \mathrm{~mm}$ height. The figure 4.2 depicted the view of rotary weeder

Table 2.1 shows the specification of different parts of the rotary weeder with their material of construction

\section{Self-propelled power unit}

A self-propelled power unit is developed at the workshop of CAE, JNKVV, Jabalpur, with the power by the Honda engine of 1.3 (hp) petrol engines. It is a compact low weight machine, self-propelled with a positive drive system by using a chain and sprocket system. It consists of a frame, handle, engine, wheel, cono weeder, chain, sprocket, bearing hub, throttle system, etc. The engine operated at 5000 (rated rpm), however, at 1/3 throttle position the speed was found to be $1800 \mathrm{rpm}$ at no-load condition. Overall dimensions developed self-propelled power unit was shown in figure 2.2. The brief specifications of the self-propelled power unit in table 2.2.

\section{Machine parameters}

\section{Travel speed $(\mathbf{k m} / \mathbf{h})$}

To determine the travel speed of the machines during weeding operation, the time required for covering $10 \mathrm{~m}$ row length was recorded. Three measurements were recorded in each operation and the average value was calculated. A digital stopwatch was used to record the time in seconds to cover a $10 \mathrm{~m}$ distance by weeders. The sensitivity ofthe stopwatch is 0.01 seconds.

\section{Effective working width (mm)}

The effective width of the weeder shall be the effective width of the weeding. In the case of weeder having provision for width adjustment, the minimum and maximum width shall be measured. The working width 
of the developed weeder was $150 \mathrm{~mm}$ but it was found that the effective width was a little less than the theoretical actual width. To measure the actual width of the weeding, a measuring tape of $5 \mathrm{~m}$ length was used.

\section{Theoretical field capacity (ha/h)}

Theoretical field capacity is the rate of field coverage that would be obtained if the weeder was operating without interruptions. It is based on theoretical width and speed. The theoretical field capacity was calculated by using the formulae.

Theoretical field capacity $(\mathrm{ha} / \mathrm{h})=$ Width of the implement $(\mathrm{m}) \mathrm{x}$ Speed of operation $(\mathrm{km} / \mathrm{h})$ 10

\section{Actual field capacity (ha/h)}

The actual field capacity is the actual average rate of field coverage. It includes turning losses, choking, making adjustments, etc. It is recorded in hectare/hour.

The actual field capacity was calculated as per the following equation:

Actual field capacity $(\mathrm{ha} / \mathrm{h})=$

Actual width of field coverage (m) XLength of field coverage (m)

Time for covering total area (h) $\mathrm{x} 10000$

\section{Field efficiency $(\%)$}

The field efficiency was calculated using equation:

Field efficiency $(\%)=$

$\frac{\text { Actual field capacity }(\mathrm{ha} / \mathrm{h})}{\text { Theoretical field capacity }(\mathrm{ha} / \mathrm{h})} \times 100 \quad \ldots$ (5)

\section{Weeding efficiency (\%)}

To determine the weeding efficiency at four places of each plot a frame of $1 \times 1 \mathrm{~m}$ was thrown in the field randomly and the numbers of weeds were counted before and after weeding operation. The weeding efficiency of the weeders was calculated by the following equation (Remesan et al., 2007):

$\mathrm{WE}=\frac{\mathrm{N} 1-\mathrm{N} 2}{\mathrm{~N} 1} X 100$

Where,

$\mathrm{WE}=$ Weeding efficiency of the weeder $(\%)$;

$\mathrm{N}_{1}=$ Total number of weeds before weeding.

$\mathrm{N}_{2}=$ Total number of weeds after weeding.

\section{Draft measurement}

Draft is defined as the horizontal vector of the pull, parallel to the line of motion. The S-type load cell was used to measure the draft. Which could measure the draft up to the range of $1000 \mathrm{~kg} \&$ least count of load cell was 0.01 $\mathrm{kg}$.

As the load cell was fitted horizontally in the line of pull, therefore, it gave the value of draft directly in kgf. Load cell was placed between power tiller and power unit. Power tiller pulled the power unit at a speed of 2.5 $\mathrm{km} / \mathrm{h}$.

\section{Fuel consumption (1/ha)}

Fuel consumption was measure by using the top up method. The fuel tank was filled to full capacity before and after test. Amount of refueling after the test was recorded. The measuring flask capacity of 1 liter was used to measure the fuel.

Fuel consumption $=\frac{\text { Fuel consumption }(\mathrm{m} / \mathrm{s})}{\text { Area covered }\left(\mathrm{m}^{2} / \mathrm{s}\right)} \times 10 \ldots(7)$

\section{Cost of operation}

In order to compare weeding cost, fixed and variable cost were calculated. 


\section{Fixed costs}

In this study, fixed costs like costs of insurance, taxes and shelter are considered negligible.

\section{Depreciation}

This cost mirrors the reduction in worth of a machine with use (wear) and time (obsolescence). While actual depreciation would rest on the sale price of the machine after its use straight-line method was used to calculate the depreciation value.

$$
D=\frac{\mathrm{p}-\mathrm{s}}{\mathrm{L}}
$$

Where,

$\mathrm{D}=$ depreciation cost, average per year;

$\mathrm{P}=$ cost price of the machine;

$\mathrm{S}=$ residual value of the machine; and

$\mathrm{L}=$ useful life of the machine in years.

The depreciation value per hour can be assessed by dividing $\mathrm{D}$ by the number of hours the machine is anticipated to be utilized in a year. Residual value $(\mathrm{S})$ of the machines may be taken as $10 \%$ of the Actual cost price.

\section{Interest}

An annual charge of interest was calculated taking 12 percent of average purchase price as basis. Average purchase price was calculated using the formula given below.

$\mathrm{A}=\frac{\mathrm{P}+\mathrm{S}}{2}$

Where

$\mathrm{A}=$ average purchase price;

$\mathrm{P}=$ purchase price of the machine; and

$\mathrm{S}=$ residual value of the machine.

\section{Variable cost}

Variable costs include fuel, lubricant, repair and operator costs and are directly related to the amount of work done by the machine. Repair cost for the weeders was considered $5 \%$ of purchase value and lubricant cost was accounted to be $3 \%$ of fuel cost (Remesan et al., 2007).

\section{Fuel}

The actual fuel consumption in each treatment was observed and estimation was done accordingly.

\section{Wages and Labour charges}

The cost of labor was estimated to take the prevailing rate of $\square 22.87$ per hour or $\square 250$ per day.

\section{Results and Discussion}

Field performance of weeder (manual and power operated touchi gurma)

Details of the performance evaluation conducted for touchi gurma attached with developed power unit (T1) and manually operated touchi gurma (T2) are shown.

\section{Performance and evaluation of weeders}

Table 3.1 revealed that the mean value of the effective field capacity of $\mathrm{T}_{1}$ andT2were found to be 0.0167 and 0.0099 ha $\mathrm{h}^{-1}$ respectively. The maximum field capacity (i.e.0.0167ha $\mathrm{h}^{-1}$ ) was obtained with $\mathrm{T}_{1}$ treatment followed by $\mathrm{T}_{2}$ (i.e. $0.0099 \mathrm{ha} \mathrm{h}^{-1}$ ). power unit with touchi gurma $\left(\mathrm{T}_{1}\right)$ the operational speed is more than manually operated touchi gurma weeding method. Among the two methods the power unit with touchi gurma had highest field capacity because of its operational speed. The 
statistical analysis of data revealed that the two treatments differ significantly for the field capacity. The mean value of field efficiency of $T_{1}$ and $T_{2}$ were found to be 91 and 80 percent respectively. The field efficiency, which indicates ratio of useful working time to the total working time, was obtained maximum in $\mathrm{T}_{1}(91 \%)$ treatment and minimum in $\mathrm{T}_{1}(80 \%)$ treatment. Similar findings was reported by Parida (2002), Tajuddin (2009), Remesan et al., (2007). The travel speed of the two treatments is presented in Table3.1. The result revealed that the higher travel speed was found in power unit with touchi gurma i.e., $2.36 \mathrm{~km} \mathrm{~h}^{-1}$ and lowest travel speed in manually operated touchi gurma i.e., $1.55 \mathrm{~km} \mathrm{~h}^{-1}$.
Figure 3.3 revealed the weeding efficiency of $\mathrm{T}_{1}$ andT2and were found to be 77.65 and 81.49 respectively. The highest weeding efficiency with $\mathrm{T}_{2}$ may be due to and fromotion in manual touchi gurma operation.

\section{Draft of the power unit with weeders}

From the experiment, it is found that the draft of the power unit with and without weeder attachment was 19.179 and9.475 kgf. The actual draft required for weeder attachment i.e.,touchi gurma was $9.704 \mathrm{kgf}$. A similar opinion was also reported by Anantachar et al., (2013).

Table.2.1 Brief specification of rotary weeder

\begin{tabular}{|c|c|c|}
\hline Sl.No & Particulars & Dimensions \\
\hline $\mathbf{1}$ & Overall dimension $(\mathrm{L} \times \mathrm{B} \times \mathrm{H}), \mathrm{mm}$ & $1870 \times 460 \times 950$ \\
\hline $\mathbf{3}$ & Working width, mm & 80 \\
\hline $\mathbf{4}$ & Number of rotors & 950 \\
\hline $\mathbf{5}$ & Height of Handle from Ground & $1.6,2$ \\
\hline $\mathbf{6}$ & No. of blade in rotor & 460 \\
\hline $\mathbf{7}$ & Blade thickness, mm & $160 \times 90 \times 35$ \\
\hline $\mathbf{8}$ & Width of handle & serrated blade -6 \\
\hline $\mathbf{9}$ & Size of Float $(\mathrm{L} \times \mathrm{B} \times \mathrm{H}), \mathrm{mm}$ & $\mathrm{m}$ \\
\hline
\end{tabular}

Table.2.2 Brief specification self-propelled power unit

\begin{tabular}{|c|c|c|}
\hline Sl.No & Details & Particulars \\
\hline $\mathbf{1}$ & Overall dimension $(\mathrm{L} \mathrm{x} \mathrm{B} \mathrm{x} \mathrm{H),} \mathrm{mm}$ & $1650 \times 200 \times 1150$ \\
\hline $\mathbf{2}$ & Weight in $\mathrm{kg}$ & 20 \\
\hline $\mathbf{3}$ & Height of Handle from ground, mm & 4050 \\
\hline $\mathbf{4}$ & Width of handle, $\mathrm{mm}$ & 2.5 \\
\hline $\mathbf{5}$ & Speed of operation, $\mathrm{km} / \mathrm{h}$ & $150 \times 200 \times 100$ \\
\hline $\mathbf{6}$ & Size of float $(\mathrm{L} \times \mathrm{B}$ B $\mathrm{H}), \mathrm{mm}$ & 400 \\
\hline $\mathbf{7}$ & Diameter of ground wheel, $\mathrm{mm}$ & \\
\hline
\end{tabular}


Table.3.1 Field performances of Power unit attached Touchi Gurma (T1) and manually operated touchi gurma (T2)

\begin{tabular}{|c|c|c|c|}
\hline SI No. & Performance Parameter & \multicolumn{2}{|c|}{ Result } \\
\cline { 3 - 4 } & & T1 & T2 \\
\hline $\mathbf{1}$ & Theoretical field capacity (ha/h) & 0.01824 & 0.0124 \\
\hline $\mathbf{2}$ & Effective field capacity (ha/h) & 0.0167 & 0.0099 \\
\hline $\mathbf{3}$ & Field efficiency $\mathbf{( \% )}$ & 91 & 80 \\
\hline $\mathbf{4}$ & Operating speed $\mathbf{( k m} / \mathbf{h})$ & 2.36 & 1.55 \\
\hline $\mathbf{5}$ & Weeding Efficiency $\mathbf{( \% )}$ & 77.65 & 81.49 \\
\hline
\end{tabular}

Table.3.5 Labour required in different weed control methods (man-hha ${ }^{-1}$ ) and cost of operation (Rs/ha)

\begin{tabular}{|c|c|c|c|c|c|}
\hline \multirow[t]{2}{*}{ Treatments } & \multicolumn{2}{|c|}{ Labour required (man-h/ha) } & \multicolumn{3}{|c|}{ Cost of operation } \\
\hline & $\begin{array}{c}\text { Weeding } \\
\text { (man-h/ha) }\end{array}$ & $\begin{array}{c}\text { Labour time } \\
\text { saving (\%) }\end{array}$ & $\begin{array}{l}\text { Labour cost } \\
\text { (Rs/ha) }\end{array}$ & $\begin{array}{c}\text { Operation } \\
\operatorname{cost}(\mathrm{Rs} / \mathrm{ha})\end{array}$ & $\begin{array}{c}\text { Operation cost } \\
\text { saving }(\%)\end{array}$ \\
\hline Hand weeding* & 166.5 & Base & 5203.12 & 5203.12 & Base \\
\hline T1 & 59.88 & 64.03 & 1871.25 & 2725.25 & 47.62 \\
\hline $\mathbf{T} 2$ & 100.20 & 39.81 & 3131.25 & 3131.25 & 39.82 \\
\hline
\end{tabular}

Fig.2.1 Pictorial view of manual rotary weeder

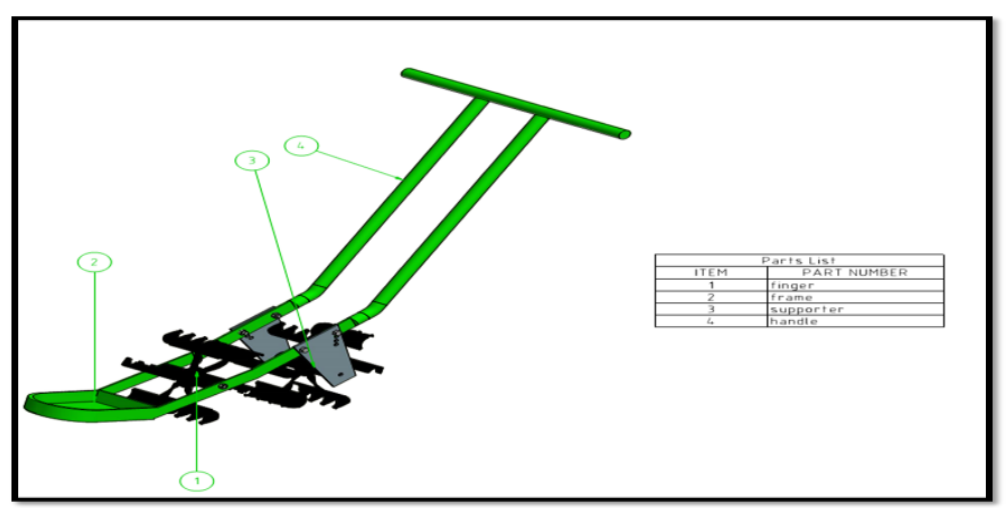

Fig.2.2 Orthographic view of power unit with rotary weeder (touchi gurma)

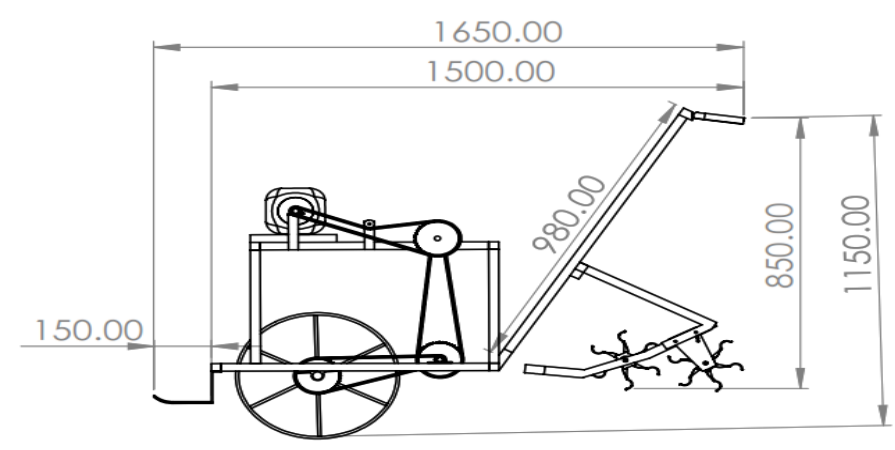


Fig.3.1 Weeding efficiency of weeding methods

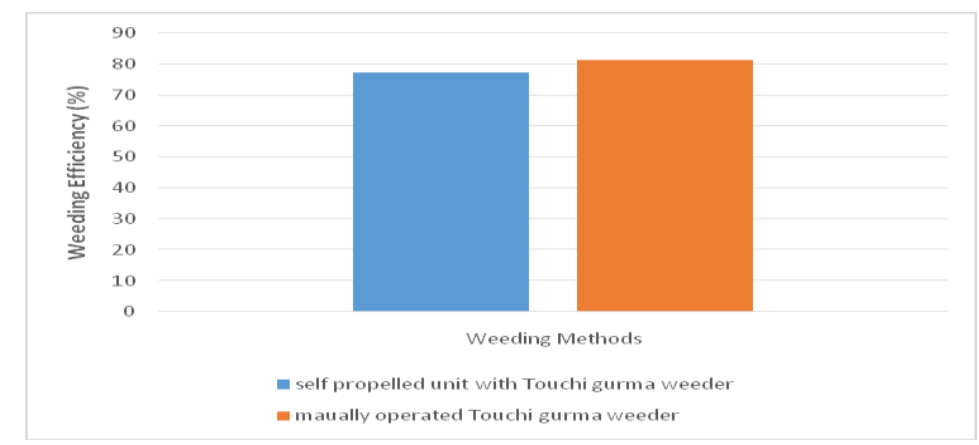

\section{Labour requirement and cost of operation in different weeding methods}

Table 3.2. shows that the total manual working hours and cost of weeding operation of different weeding methods. The time required for controlling the weeds by Manual weeding method taken as base period and calculated the labor-saving for different mechanical methods. Table 3.2reveals that the time saving was a maximum of $64.03 \%$ for the T1 (power unit with touchi gurma) and a minimum of $39.81 \%$ for the T2 (manually operated touchi gurma).The operating cost of T1 andT2 was 2725.25 and3131.25 Rs/ha respectively.

\section{Fuel consumption}

It is evident from the experiment that the fuel consumption in weeding operation by the power unit with touchi gurma at the speed of $2.28 \mathrm{~km} / \mathrm{h}$ was found to be $6.5 \mathrm{l} / \mathrm{ha}$.

In conclusions the performance of the developed self-propelled unit with touchi gurma was compared with the manually operated touchi gurma. The different mechanical parameters were measured which include field capacity, field efficiency, travel speed, labor required, weeding efficiency, cost of operations.

Amongst the two weeders (i.e., power unit with touchi gurma and manual touchi gurma) field capacity was found to be maximum i.e., $0.167 \mathrm{ha} / \mathrm{h}$ for power unit with touchi gurma and a minimum of $0.0099 \mathrm{ha} / \mathrm{h}$ for manual touchi gurma.

Amongst the two weeders (i.e., self-propelled and manual) field efficiency was found higher in self-propelled unit touchi gurma having $91 \%$ which is higher than the manual operated touchi gurma of $80 \%$.

Minimum manual work hours required for controlling the weed were related in self-propelled unit with touchi gurmai.e.,59.88 man-h/ha as compared with manually operated touchi gurmai.e., $100.20 \mathrm{man}-\mathrm{h} / \mathrm{ha}$.

The operational cost of weeding was maximum in manually operated touchi gurma of $1871.25 \mathrm{Rs} / \mathrm{ha}$ as compared with self-propelled unit touchi gurma of $3131.25 \mathrm{Rs} / \mathrm{ha}$.

The draft was found in self-propelled unit touchi gurma having $9.04 \mathrm{kgf}$.

The result indicates that self-propelled unit touchi gurma contributes maximum efficiency with least fatigue.

\section{References}

Agricultural Statistics at a glance 2014, http://eands.dacnet.nic.in/

Anantachar M, Sushilendra, Lokesh, Sunil Shirw Al, RaghaVendra and Mareppa. 2013 Performance evaluation of touchi 
gurma for paddy in farmer's field. Engineering and Technology in India, 4 (1):14-16.

Grandjean E. 1988. Fitting the task to the man. Taylor and francis,London, $4 \mathrm{ed}$. $363 \mathrm{p}$.

Vijayakumar, MS, Chandrasekaran RB and Thiyagarajan TM. 2006. Influence of system of rice intensification (SRI) practices on growth characters, days to flowering, growth analysis and labor productivity of rice. Asian Journal of Plant Sciences, 5 (6): 984-989.

Parida BC. 2002. Development and evaluation of star-cum cono weeder for rice. Agricultural Mechanisation in Asia, Africa and Latin America, 33(3): 21-22.

Rai M. 2004. DARE/ICAR annual report. http://www.icar.org.in/files/ar0304/08agricultural $\% 20$ engineering $\% 20$ and $\% 2$ Otechnology.pdf.

Rainbird G and O’Neill DH. 1955. Occupational disorders affecting agricultural workers in tropical developing countries. Appl Ergon,1995, 26:187-193.
Rangasamy K, Balasubramanium $\mathrm{M}$ and Swaminathan KR. 1993. Evaluation of power weeder performance, Agricultural Mechanisation in Asia, Africa and Latin America, 24 (4):16-18.

Remesan R, Roopesh MS, Remya N and Preman PS. 2007. Wet Land Paddy Weeding- A Comprehensive Comparative Study from South India. The CIGR journal. Manuscript PM 07011, 9: 1-21.

Sharma DN and Mukesh S. 2013. Farm machinery design. jain brother publication. New Delhi. pp 195-196.

Singh S P, Singh M K AND Solanki R C. 2016. Design and development of fourwheel weeder for wide-row crops. Indian Journal of Agricultural Sciences 86(1): 42-49.

Tajuddin NM, Tarmizi RA, Konting MM and Ali WZ. 2009. Instructional Efficiency of the Integration of Graphing Calculators in Teaching and Learning Mathematics, International Journal of Instruction, 2(2): 11-30.

\section{How to cite this article:}

Krishna Kanth, B., A. K. Shrivastava and Jitendra Bairwa. 2021. Performance and Evolution of Touchi Gurma Weeder with Developed Self-propelled Power Unit. Int.J.Curr.Microbiol.App.Sci. 10(02): 59-66. doi: https://doi.org/10.20546/ijcmas.2021.1002.007 